
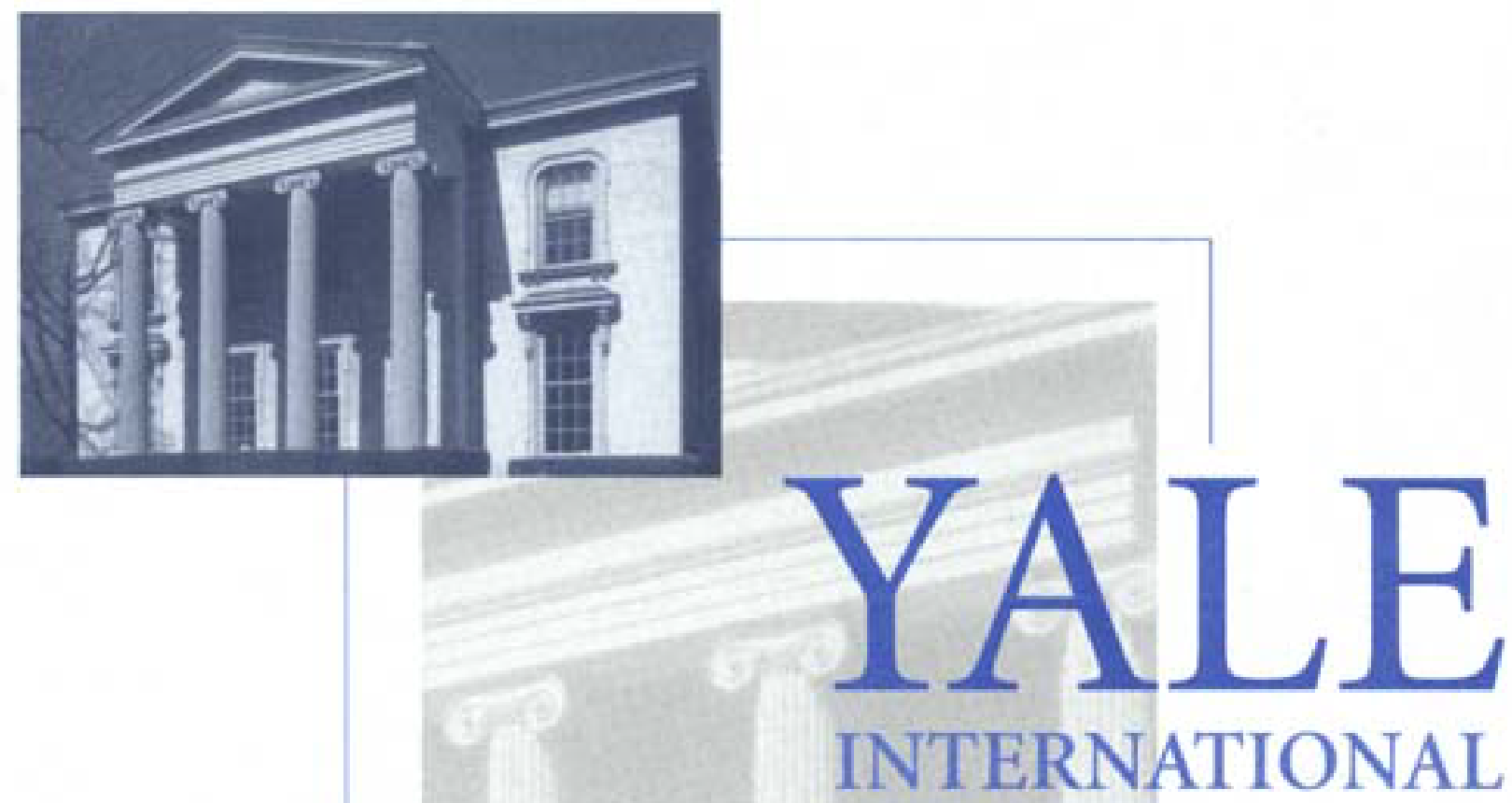
CENTER FOR FINANCE

Behavioral Factors in Mutual Fund Flows

\author{
William N. Goetzmann \\ Yale School of Management \\ Massimo Massa \\ INSEAD \\ K. Geert Rouwenhorst \\ Yale School of Management
}




\title{
Behavioral Factors in Mutual Fund Flows
}

\author{
William N. Goetzmann, Yale School of Management \\ Massimo Massa, INSEAD \\ K. Geert Rouwenhorst, Yale School of Management
}

\begin{abstract}
Using a sample of daily net flows to nearly 1,000 U.S. mutual funds over a year and a half period, we identify a set of systematic factors that explain a significant amount of the variation in flows. This suggests the existence of a common component to mutual fund investor behavior and indicates which asset classes may be regarded as economic substitutes by the participants in the market for mutual fund shares. We find that flows into equity funds -- both domestic and international -- are negatively correlated to flows to money market funds and precious metals funds. This suggests that investor rebalancing between cash and equity explains a significant amount of trade in mutual fund shares. The negative correlation of equities to metals suggests that this timing is not simply due to liquidity concerns, but rather to sentiment about the equity premium.
\end{abstract}

We address the question of whether behavioral factors spread returns by using the mutual fund flow factors as pre-specified regressors in a Fama-MacBeth asset pricing framework. We find that the factors derived from flows alone explain as much as $45 \%$ of the cross-sectional variation in mutual fund returns. The fund flow factors provide significant incremental explanatory power in the cross-sectional regressions on daily returns.

We consider a number of alternatives to explain our evidence including causality from returns to flows and vice-versa. Our evidence is consistent with the existence of a pervasive investor sentiment variable.

Acknowledgements: We thank Mark Grinblatt and Jeff Wurgler for helpful comments. We thank Trimtabs for providing data for analysis. For a current draft, please contact William Goetzmann at william.goetzmann@yale.edu. 


\section{Introduction}

An important requirement of Ross' (1976) Arbitrage Pricing Theory [APT] is that investors perceive and care about a parsimonious set of factors driving asset returns. This requirement is fundamentally a behavioral one, however the quest for the factors in the APT has generally focused on asset returns and macro-economic variables rather than on individual portfolio choices. This is somewhat surprising -- what better way to understand the factors in the economy that matter most to investors than to look at what portfolios they actually hold and trade?

One promising place to look for evidence on APT factors is the mutual fund sector. The mutual fund industry now represents a substantial part of the domestic marketplace for securities. Perhaps more relevant, the industry is, in effect, a retail market for portfolios, rather than for individual stocks and bonds. Share purchase decisions by fund customers is not likely to be based upon the prospects of an individual security, but on the prospects for the broad asset class that the fund represents. In this marketplace for portfolios, we would expect consumer demand to determine the types of portfolios that fund companies provide. Thus, in an asset pricing framework, the range of funds in the marketplace should ultimately reflect the factors most relevant to the consumer. In particular, to the extent that the stylized assumptions supporting K-fund separation hold (c.f. Ross, 1978), we would expect to find these K-funds in the mutual fund marketplace. By the same token, net flows across major asset classes in the mutual fund sector can be interpreted as aggregated rebalancing decisions across factor portfolios.

In this paper, we use a sample of daily net flows to nearly 1,000 U.S. mutual funds over a year and a half period to identify a set of systematic factors that explain a significant amount of the 
variation in mutual fund sector flows. The implication of these factors is simple, but powerful. They suggest the existence of strong, common components to mutual fund investor behavior. Among other things, these components provide a measure of the degree to which investors herd across asset classes on a daily basis -- the most influential component explains as much as $18 \%$ of the variation in net flows, and the top three factors explain about $26 \%$ of variation.

We identify the most important flow factor with a strong stock-bond contrast. The flows into equity funds -- both domestic and international -- are highly negatively correlated to flows to money market funds and precious metals funds. This suggests that investor reallocation between cash and equity explains a significant amount of net demand for mutual fund shares. The negative correlation of equities to metals suggests that this timing is not simply due to the use of money funds as checking accounts before and after holding stocks, but perhaps to changing beliefs and expectations about the equity premium.

While it may seem simple, since it is a fundamental requirement of the APT, we are able to document that investors regard correlated portfolios as economic substitutes. This is useful, since a crucial step in the logic of the APT is that investors perceive and care about a parsimonious set of factors that are statistical drivers of asset returns. This key behavioral link has never been explicitly documented in the empirical asset pricing literature, however. It, in fact, justifies the common exercise of extracting APT factors from the covariance matrix of returns. It is well known that, in the context of the APT, correlations among a set of assets does not imply that these represent a priced factor. However if these asset portfolios are used by a large class of investors who change portfolio weights on them when they re-balance, it is more likely that these are factors that investors 
both perceive and care about in the context of exposure to risk. Thus, the flow information further validates the analysis of the covariance of returns for identifying a parsimonious set of risk factors.

Elton, Gruber and Blake (1996) make a strong case for the use of mutual fund returns as a fruitful place to search for priced APT factors. Brown, Goetzmann and Grinblatt (1997) show that factors extracted from the mutual fund universe perform well as factors in an APT model. However, neither of these papers uses direct access to flow information that could be used to analyze fund groups that are used by investors in re-balancing decisions. Thus the current paper takes a step beyond asset and fund returns to a more primitive level in the APT -- to investor perceptions. As a result, we find factors in the flows that may provide significant improvement in explaining returns in the cross-section, and which we conjecture should be priced.

We put behavioral-based factors to the test by examining the extent to which they provide incremental improvement over factors extracted from returns. While one might think that it is difficult to improve on returns-based factors which are in turn used to explain returns, the logic of using behavioral factors is that information about what investors actually perceive as substitutes might actually be superior to statistical estimation of factors out if sample. Alternately, the very beliefs that drive investor action to rebalance portfolios might themselves be priced.

We address the asset pricing question of whether behavioral factors spread returns by using the mutual fund flow factors as pre-specified regressors in a Fama-MacBeth asset pricing framework. Not only are fund returns correlated contemporaneously to flows, but the exposure to these flow factors explain as much as $45 \%$ of the cross-sectional variation in mutual fund returns.

In an attempt to understand the motives for portfolio re-balancing, and the relationship 
between asset returns and investor choice, we examine the daily correlation between flows and returns. We find strong and somewhat surprising links between re-balancing decisions by fund investors and contemporaneous daily returns. This is particularly relevant to the field of behavioral finance, because the crucial link between asset pricing and behavioral finance is the identification of processes by which individual and institutional investment decisions -- rational or otherwise -affect security prices. Researchers can show that many market anomalies such as the profitability of value investing or momentum investing are consistent with the wide use of cognitive heuristics and biases such as loss-aversion and over-confidence. Experiments have demonstrated that individuals display tendencies toward these psychological heuristics and biases. ${ }^{1}$

Never-the-less, security markets are essentially anonymous. It is difficult to even identify individual decisions to trade, much less to analyze the grounds for the decision, the time such a decision is made, the price impact (if any) of the decision, and the dynamics of the price path following the decision. Indeed, not only is it difficult to study such a process, it may be meaningless. Given the millions of individual decisions that determine prices each day in the world capital markets, we expect that most purchase and sale decisions for securities will have no discernable or sustained impact unless there relative size is extraordinary, or unless they share some common component. For example, research has shown that block trades and purchases by index funds can move prices. ${ }^{2}$ In the latter case this is clearly due to the common demand for a stock by a relatively large sector of institutional investors. ${ }^{3}$ Time-series studies with long-term data about flow of funds as well as high freqeuncy data about flow of funds suggests that demand changes in certain sectors of the market may have a price impact -- even what the investors individually are 
small. $^{4}$

Thus, if the demand is large enough either due to the magnitude of the trade, the magnitude of the institution or the breadth of demand across investors, we might expect to find some price effects associated with rebalancing. Large trades have been studied, but aggregated demand curves are difficult to clearly identify. Indirect evidence on the shape of the demand function for assets has been found by focusing on the effects produced by the additions of a stock to an index. Shleifer (1986), Garry and Goetzmann (1986) Harris and Gruel (1986), Dhillon and Johnson (1991) and Lynch and Mendenhall (1997) find that additions to the index increases share prices and delisting decreases share prices. This can be interpreted (Shleifer (1986) and Harris and Gurel (1986)) as an indirect evidence of a downward sloping demand function.

The strong evidence of contemporaneous correlation between returns and flows has three potential explanations we consider. The first is that positive movement in the prices of assets in a particular asset class (or factor) causes investors to increase their weight on that portfolio immediately within the day. Given a lack of strong lagged response to returns we do not believe this is the principal cause. The second explanation is that investor share purchases in a certain type of mutual fund leads to an immediate price increase is assets in that fund. Evidence from international funds seems to rule this explanation out. The third possibility is that both prices and flows are responding to a third factor. Presumably, this factor pertains to common expectations about the equity premium. This last story is consistent with the Delong, Shleifer, Summers and Waldman proposition that noise-trader risk, if pervasive, may be priced.

The paper is organized as follows. Section 2 describes the data. Section 3 reports the factor 
structure of fund flows. Section 4 reports the results of the Fama-MacBeth analysis. Section 5 considers alternative explanations for the results. Section 6 concludes.

\section{Data}

We purchased data from TrimTabs, a firm which tracks the net flows for almost one thousand U.S. mutual funds. Our TrimTabs sample contains daily total net assets [NAV] and daily net asset values per share [NAVPS] for 999 open-end mutual funds over the period January, 1998 through July, 1999. Trimtabs constructs net fund flow $[\mathrm{F}]$ under the assumption that money comes into the fund at the end of the day. That is, $\mathrm{F}(\mathrm{t})=\mathrm{NAV}(\mathrm{t})-\mathrm{NAV}(\mathrm{t}-1)(\mathrm{NAVPS}(\mathrm{t}) / \mathrm{NAVPS}(\mathrm{t}-1)) .^{5} \quad$ Several researchers have identified data errors and timing problems with the TrimTabs flow variable. TrimTabs flow is typically rounded to a single decimal and sometimes the calculation does not correspond to the calculation above. For that reason, we compute our own $F(t)$ from the NAV and NAVPS, and we examine it for suspicious outliers that may be due to large, incorrect NAV changes. Another potentially important issue is that some funds in the TrimTab database report NAV before the net purchases and shares for the day. ${ }^{6}$ Note that, if the fund return were zero for the current day and the day following, this would have the effect of lagging forward the flow by a day. Since returns are not zero, this interpretation is not precise and its value as an approximation depends on the variation in fund returns. In an analysis of a subset of the TrimTabs funds Goetzmann, Ivković and Rouwenhorst (1999) find the percentage of funds reporting "late" in this manner is less than 5\%, with more than $75 \%$ reporting on-time. The remainder sometimes reported "late" and sometimes reported on-time. Thus, any interpretation of lagged effects with the TrimTabs data should consider 
the potential effects of these errors. ${ }^{7}$

The assets in the 999 funds in the sample represented $\$ 738$ billion in April 1998 and $\$ 851$ billion by the end of June 1999. The Investment Company Institute website reports the universe of U.S. mutual funds in April, 1998 to be 6,809 funds holding \$5.048 Trillion. These measures suggest that our sample represents something like $15 \%$ of all assets in mutual funds. The Investment Company Institute also reports that, as of the end of 1997, U.S. mutual funds held an estimated $19 \%$ of all U.S. listed stocks. Thus in our sample neither comprises a majority of the U.S. security market capitalization, nor a majority of U.S. mutual fund money. Never the less, at $\$ 851$ billion, a large amount of money is represented.

The 999 funds represent fifty different investment objectives. Table 1 cross-tabulates the reported fund objectives with eight asset classes into which we have sorted most of the funds. Some funds are omitted due to their overlap across categories. Because we are interested in unambiguous asset classes, we have not coded hybrid funds nor world equity funds into the asset classes. As the table indicates, we do not have a large number of money-market funds -- indeed the closest proxy we have are ultra-short bond funds which are sold to mutual fund investors as close substitutes to money market funds. The daily fund flows we study are small relative to the total assets under management. The average percentage daily net flow to a fund is $.018 \%$ of NAV or $\$ 170,000$.

\section{Factor Structure of Fund Flows}

\section{III.1 Flow Correlations}

Are there common factors in the cross-section of mutual fund flows? It is not obvious that 
behavior should be correlated across investors or funds, however we presume that there are common shocks to people's income. It also seems likely tat investors will commonly respond to news events that have similar implications across investors in terms of portfolio choice. What is striking in our data is the extent to which investor decisions are correlated on a daily basis.

Table 2 reports the correlation of flows and returns for the major asset classes in our sample. The first panel of the table uses the total net flow across funds in the sample for that day for all funds in the category. ${ }^{8}$ Thus the addition of a new fund to the sample is not interpreted as new money, but money inflow to a fund due to a merger will be. The second panel uses equal-weighted percentage change in fund assets due to new money flows as a measure. Thus, it captures the average flow effects more broadly across funds. The third panel reports the correlations of asset portfolio class returns, where the asset class portfolios are equally-weighted across all the funds in the asset class. Our goal in showing dollar-weighting and equal-weighting is to avoid a situation in which a few large funds within one asset class dominate the results.

The most striking feature of both the dollar-weighted and equal-weighted flow correlation matrices is the negative correlation between cash and equity flows. On days when money flows into stock funds, it flows out of cash funds. This may not seem too surprising given that investors use short-term fixed income accounts virtually as checking accounts. Perhaps the cause of the negative correlation is that salary is paid into a money market account and then investors purchase shares of stock funds by transferring the money out of the money market account. While this is a logical mechanism, in the absence of seasonality in the data, it does not explain the strong, daily correlation of the flows. ${ }^{9}$ Another possibility is that investors quite broadly follow a portfolio 
insurance strategy that entails a dynamic allocation between equities and cash. This is potentially testable. A third possibility is that these flows represent changing expectations about the equity premium. In fact, there is some evidence in Table 2 to support this last hypothesis. Notice that the flows to precious metals funds are slightly negatively correlated to the flows to stock funds. Gold is typically regarded as investment for troubled times. Historically, gold returns have been negatively correlated to stock returns, although in the period of our study, the correlation to gold funds and stock funds is actually positive. Investment in gold, however, is a sign of negative sentiment about the future returns to stocks. Gold funds -- unlike cash funds -- are unlikely to be used for explicit or implicit portfolio insurance strategies.

The evidence on U.S. bond funds is qualitatively similar to evidence on cash funds. They are negatively correlated to equity flows, although the magnitude of the negative correlation for equal-weighted percentage flows is smaller in magnitude. For world bonds, the sign of the correlation is positive.

Another striking feature of Table 2 is the high correlation between U.S. and foreign equity fund flows. We removed world stock funds from the foreign equity asset class because they typically hold about $30 \%$ in U.S. equities. Thus we restrict our attention to funds holding only nonU.S. stocks. The correlation of $60 \%$ to $70 \%$ (depending upon the measure) suggests that foreign equities are treated by mutual fund investors as economic substitutes for U.S. equities. In fact, the correlation between U.S. and foreign equity fund flows is higher in our sample than the daily returns on funds themselves.

Finally, it seems somewhat odd that flows to municipal bond funds are essentially 
uncorrelated to flows of other bond funds. Apparently municipals are not regarded as economic substitutes for other debt funds, nor as a haven form the stock market.

\section{III.2 Factor Analysis: Principal Components Approach}

The asset class groupings clearly represent a useful rotation of the fund flows for purposes of identifying the composition of factor portfolios as the participants in the mutual fun $\mathrm{d}$ market place perceives them. A natural question to as is how much of the variation on flows may be explained by these factors? This is a useful question to address in terms of research in behavioral finance, because much has been written about herd behavior. One measure of the extent of herding is the amount of variance explained by the first principal components. In addition it is potentially useful to understand how many components in the data have significant explanatory power. If a new funds span returns, this may help us understand how large $\mathrm{K}$ is in the empirical analogue to $\mathrm{K}$-fund separation.

We construct dollar-weighted and equal-weighted flow series' for each of the fifty fund objective categories in our sample. We extract the principal components from these series.' The associated eigenvalues provide a measure of the amount of variance explained by each rotation of the series.' For dollar-weighted flows, the first second and third principal components explain $18.9 \%, 4.7 \%$ and $4.2 \%$ respectively. For equal-weighted flows, the the first second and third principal components explain 16.8\%, 4.2\% and 3.7\%. Both suggest that the first principal component explains most of the variation in mutual fund investor purchase and sale decisions. Of course, this is by construction and Brown (1989) shows that a single large factor does not provide 
contrary evidence of the number of factors relevant to investors. The possibility exists that investors would need a number of fund choices to achieve the payoff provided by the rotation of the first component. To examine this, we match the weights to the major fund categories. Table 3 reports the weights for the first four principal components for the dollar-valued objective category series. The component weights tell the same story as the correlation matrices. The first component clearly is the polarity between flows to stock funds and flows to bond funds. It thus would require two funds to achieve. The next three components are difficult to interpret.

Table 4 provides a clearer picture of the factors. It reports the principal component weights for all of the eight factors extracted from the time-series of the major asset class flows. As in Table 3, the first factor is constructed as the difference between stock and bond fund flows. It explains more than $30 \%$ of the cross-sectional variation. The second factor has a strong loading on non-U.S. equity and loadings of the opposite sign on everything else. This suggest there may be an international equity component to the flow structure. The third component loads heavily on the metals funds and has a weight of the opposite sign on the specialty class. Specialty funds are industry-focused funds. A portfolio of their returns should be (and is) correlated to U.S. equities. The flows into these funds, however are not necessarily driven by beliefs about the market as a whole. They are by their very nature non-diversified, so flows into specialty funds represent investors taking sector-focused bets in communications, financials, technology, natural resources, health care, utilities and real estate. Thus, the third factor might be a sector-bet factor, orthogonal to a bet on the equity market by construction. The fourth factor appears to have a natural interpretation as well. It has a high weight on U.S. bonds and a negative weight on non-U.S. bonds. 
This appears to be a foreign bond factor, however a significant weight on the municipal bond flows makes this interpretation ambiguous. The remaining four factors together explain about $30 \%$ of the remaining variance, however they are difficult to interpret. The bottom panel in the table reports the principal component weights for the orthogonalized equal-weighted return series. These weights suggest that the first principal component is postively weighted across asset classes, and the second factor is the spread between stock and bond returns.

Of course, a major limitation of interpreting mutual fund factors as universal factors in the economy is that we have a limited set of agents -- perhaps our results are merely a reflection of the relevant factors to our sample. This is an issue for further empirical work -- we are hopeful that the sample is broad enough to capture the key factors relevant to pricing individual securities, however. One positive sign of this is that Brown, Goetzmann and Grinblatt (1997) test factors extracted from fund returns on individual security returns and find they work well. In the current paper, as we show later, we improve on fund return factors by examining flows directly.

\section{Flow Factors and Fund Returns}

\section{IV.1 Cross-correlations}

How are flow factors related to returns? The bottom panel of Table 2 reports the crosscorrelations between dollar-valued flows and asset class returns. U.S. equity returns are correlated to daily U.S. equity flows, world equity returns are correlated to world equity flows and precious metal fund returns are correlated to precious metals flows. The other asset classes do not display high correlations between flows and returns. A striking feature of the cross-correlations is that world 
equity flows are correlated to U.S. equity returns -- more so than the world equity flow correlation to world equity returns.

The cross correlation of flows and returns suggests the possibility that flows may be correlated across asset classes because returns are correlated across asset classes. For example, perhaps investors purchase shares in asset classes whose return is high in the first half of the day and sell shares in asset classes whose returns are low in the first half of the day. When both asset classes rise on a given day, the flows into both will be positive. Thus, behavior is only correlated through the correlation of the returns. To address this, we orthogonalize asset class flows with respect to asset class returns by regressing the time-series of flows for each asset class on the set of eight asset class return series' and saving the residuals. ${ }^{10}$ We then calculate the correlation matrix of the orthogonalized flow factors. The correlation of orthogonalized flows, reported in Table 5, is not dramatically different from the raw flow correlations. Stocks and bond fund flows still have strong negative correlations, beyond what can be explained through their correlation to returns.

\section{IV.2 Fama-MacBeth Procedure}

While it is useful to document the correlation between customer purchase decisions, an important issue in behavioral finance is whether investor behavior has pricing implications. Our data In this section we use the Roll and Ross (1980) [RR] procedure, adapted from Fama-MacBeth (1974) $[\mathrm{FM}]$, to investigating the relative ability of behavioral factors to explain cross-sectional differences in fund returns. The FM/RR technology applied over a short time-horizon is unlikely to provide any results on whether any factor is priced, however it is useful for identifying factors that spread 
returns.

In particular, we are interested in determining whether behavioral factors based on the flows provide any additional explanatory power beyond commonly used pre-specified asset classes. Why is this interesting? At issue in tests of pricing models are two things: first, the identification of portfolios that span returns, second, the question of whether exposure to these portfolios have an associated positive expected return. The second issue is important, because we would like to know whether higher exposures to time-varying factors are associated with higher required returns, however the power of the test, as well as its relevance to asset pricing depends crucially on the first question -- what are the factors? While factors that only imperfectly span returns might be priced since they are rotations of the true factors, it would still be better to know the true set. Thus, knowing the most meaningful factors a priori will improve asset pricing model estimation and thus calculation of expected returns. If we find that using behavioral factors improve spanning of portfolio returns, then these factors either belong directly in the estimation of a pricing model or they should be regarded as instruments that correlate to meaningful factors.

More important than this, however, are broader issues beyond the question of tests of asset pricing models. If exposure to certain factors, behavioral or not, are associated with variation in returns to asset portfolios, then they represent sources of risk. In the analysis below, we find that behavioral factors are not captured by linear combinations of return portfolios. This implies that they represent a potential source of economic risk to investors. While we cannot prove these exposures are associated with higher expected (or realized) returns, the fact that they spread returns alone implies a potential hedging need -- at issue is simply the cost. 
In the section that follows, we describe the process by which we test the incremental crosssectional explanatory power of estimated exposures to fund flow factors.

\section{IV.2.1 Factors and Factor Loading Estimation}

As return factors, we simply use the returns to the eight equal-weighted asset class fund portfolios. Since some of the eight objective categories do not exist at the beginning of the sample period, thus we lose eighty days at the beginning of the sample. We construct flow factors by taking the equal-weighted percentage flow series for each asset class and regressing it on the set of eight return factors for the same day and the previous day. This insures that the pre-specified flow factors are orthogonal to the contemporaneous return factor realizations and to the return factor realizations on the preceding day. Any additional explanatory power due to the use of the flow factors is thus strictly incremental. Orthogonalizing with respect to preceding day returns as well is useful because we may potentially be observing return-chasing -- an alternative that will be discussed below. After this "twice-orthogonalization," we then estimate fund loadings on the return factors and orthogonalized flow factors for each fund that exists in the sample for at least one year. The factor loadings are estimated using only the even days in the sample. ${ }^{11}$

\section{IV.2.2 Cross-Sectional Regressions}

In stage 2, we use the factor loadings for each fund as regressors in a cross-sectional regression on each odd day in the sample period -- first using only the eight return factors and then using all sixteen factors that include the orthogonalized flow variables. For each day, we save the 
$\mathrm{t}$-statistics and $\mathrm{R}^{2}$. This allows us to test for the incremental performance of the orthogonalized behavioral factors. The results are reported in Table 6. The means and medians of the absolute values of the t-statistics associated with the return factors and orthogonalized flow factors are reported in the table. As expected, the t-statistics indicate that the return factors have high explanatory power on alternate days. Notice that the average t-statistics on the orthogonalized flow factors are significant as well. The median t-statistics on all flow variables are lower that on returns. The median U.S. and foreign equity variables are less that 2 , with medians values for the others higher. The mean and median adjusted $\mathrm{R}^{2}$ are reported below. We performed F-tests on the differences in $\mathrm{R}^{2}$ for the restricted vs. unrestricted regressions and the significance level exceeded $95 \%$ for virtually every day in the sample. An F-test performed on the total sum of squared errors across all days with and without the additional flow variables shows that the incremental explanatory power is highly significant.

\section{Discussion}

The results of the Fama-MacBeth tests suggest that the asset class flow factors are instruments that help explain cross-sectional variation in realized returns. Since we have limited our analysis to pre-specified asset classes, these factors are unlikely to be industry groups or individual security characteristics such as momentum or size, unless these characteristics are related to asset class-level flows. The orthogonalization of the flows on the returns allows us a rather

precise definition of an effect. We can interpret the results in Table 6 as evidence that when money flows into U.S. stocks funds and out of U.S. bond funds on a day when the returns to these funds do 
not necessarily differ, then funds with a high loadings on the first and/or the fifth flow factors will have higher or lower returns than predicted by their loadings on the U.S. stock factor or U.S. bond factor. What economics might explain this effect? We have four potential explanations: nonsynchronous trading, flows as demand shocks that affect security prices, flows as evidence of shortterm trend chasing by investors and finally flows as instruments for investor sentiment about asset classes.

\section{VI.1 A Fund Objective Effect?}

One possible explanation for the FM evidence is that investors are chasing the performance of certain sectors within the day and this is not captured completely by orthogonalization with respect to major asset classes. For example, suppose that when money flowed into U.S. equity funds, it went primarily into funds that had the highest returns on the morning of the day. These are likely to be sector-specific, since well-diversified funds are unlikely to be outliers. If this is true, then the loadings on the fund flows may serve as instruments for the returns of a certain sector within the class of U.S. equity funds -- small stocks, for example. By the way, note that intra-day returns to individual funds are unobservable, as are the exact fund holdings. Thus, investors in all likelihood would have to make their decisions about intra-day return chasing solely on the basis of sector or fund style information. To address the extent to which the flow factors proxy for sectors, we can use a dummy matrix for the fund objective in addition to the return factors and flow factors. ${ }^{12}$ Table 7 reports the mean and median $\mathrm{t}$-statistics and $\mathrm{R}^{2}$ from the cross-sectional regressions which include loadings on return factors, loadings of twice-orthogonalized flow factors and a set of dummies for 
each type of fund objective other than U.S. Equity. Notice that the adjusted $\mathrm{R}^{2}$ increases significant with the inclusion of the dummies for fund objective. This is consistent with the findings in Brown and Goetzmann (1997) who find that knowing the fund style is practically as useful as knowing the fund's factor loadings. Even controlling for the 50 different fund types, however we still find evidence that the loadings on flow factors provide additional cross-sectional explanatory power. An F-test of the difference in explanatory power in all cross-sectional regressions with and without the flow factors rejects the null that they add no value. It might still be possible that the flows are proxying for some specific characteristic of the fund that causes differential behavior. However, if an intra-day return chasing story is to explain the power of flow factors, it must be the case that the returns associated with the characteristic are observable intra-day. An extreme example of this is the possibility that fund flows and returns are correlated because investors buy shares in a fund that holds a particular stock that is doing well on a given day. While this explanation is feasible, it seems tenuous, given the fact that fund portfolio holdings are typically only observed quarterly, and direct purchase of the stock is much simpler.

\section{VI.3 Fund Demand Effect?}

One simple explanation for the correlation between flow-return correlation is price pressure. A flow into the fund increases the fund' s demand for the stocks it holds and the prices of those stocks rise on that day. Although mutual funds may hold only a small percentage of securities in the world markets, it may be that they are the marginal investors and thus their decisions are salient in the price formation process. This is the argument in Zheng (1999), and evidence in Goetzmann 
and Massa (1998), who study specifically the S\&P 500, is consistent with this hypothesis. They find that end-of-the-day returns to the S\&P 500 are higher on days when there are higher inflows to three large index funds. One approach to testing whether fund demand is directly affecting prices is to focus on the international funds whose markets are closed (or almost closed) when the U.S. market is open. If it is the case that flows affect returns through the fund's shift in the aggregate demand schedule for certain securities, we should not expect to see a high contemporaneous correlation between foreign equity fund returns and foreign equity fund flows. Table 2 shows that the flow-return correlation for foreign equities is positive -- about $19 \%$. When we focus only on European, Pacific and Japanese funds the correlation ranges from $20 \%$ to $32 \%$. In other words the flow factors are unlikely to be capturing demand effects for these types of funds since the returns are causally prior to flows by construction. One caveat to this is that if most funds were reporting their NAV information without including the funds for the day, flows would be effectively contemporaneous. However, only a small fraction of international funds can be shown to be late reporters.

The foreign fund evidence does not support a direct demand effect story, however the explanatory power of the loadings on flow factors suggests that a fund's correlation to sector demand shocks contains information that spreads returns out-of-sample. Perhaps, instead, the behavioral factors are instruments that capture demands shocks that extend beyond the mutual fund universe. 


\section{VI.3 A Sentiment Factor?}

The principal components analysis above suggests that the major variable captured by the fund flows is a polarity between stocks and bonds. The natural interpretation of this polarity is the fluctuation in expectations about the equity premium. One could argue that changes in expectations about the equity premium should be manifest immediately and completely in the returns to the two asset classes. However this is not necessarily true. Many investors might change their opinions about the prospects for stocks as an investment without affecting the price of stocks in aggregate. It may simply be the case that these agents are not the marginal investors. Never the less, their sentiment about the prospects for equities (or the relative attractiveness of different asset classes ) might have pricing implications for individual assets and portfolios. Delong, Shleifer, Summers and Waldman (1990) propose a model in which unpredictable variations in noise trader sentiment is, in effect, a risk factor for rational agents in the economy. In their model, the "less than rational" traders are acting in response to noise as opposed to actual news about fundamentals. This makes rational arbitrage in expectations risky for informed agents who have limited investment horizons. Intuitively, they may see an opportunity to buy a security at a discount but they cannot profit from the purchase if popular sentiment about this security is persistently negative. This, sentiment, if broad enough, is a priced risk. A crucial requirement of the DSSW model is that investor sentiment must be broadly correlated across investors to be priced. In other words, in one class of noise traders is bullish and another class is bearish, they in effect cancel each other out in terms of the risk the

present to rational, short-term traders. Our evidence in this paper suggests the existence of relatively high correlation across individual mutual fund flows, consistent with the DSSW 
requirement for priced sentiment. Our FM tests also suggest that flow factors spread returns, consistent with the hypothesis that the sentiment factor is not spanned by factors derived solely from asset returns. This is also consistent with the evidence in Lee, Shleifer and Thaler (1991) who propose closed-end fund discounts as an instrument to capture the investor sentiment variable. The show that the discount is stochastic and not perfectly correlated to the time-series of returns to the underlying assets in the closed-end fund.

\section{Conclusion}

In this paper we examine and analyze the correlation matrix of the net daily flows to a set of mutual funds over a year and a half period. We find that the matrix has structure, suggesting a relatively high level of correlated behavior across U.S. mutual fund investors. The major behavioral factor is closely linked to the difference between stock and bond fund returns, and thus may be related to expectations about the equity premium.

We use the Fama-MacBeth approach to testing the incremental power of flow factors to explain cross-sectional differences in realized fund returns. We find that flow factors, even orthogonalized with respect to current and previous-day asset class returns, provide considerable incremental explanatory power. We examine three alternative hypotheses to explain the effects. While we cannot completely rule out intra-day sector trend chasing as an explanation, when we dummy out detailed fund objective categories, the flow factor power remains. It the entire effect is intra-day trend chasing, investors must be choosing funds to chase based on intra-day observables and fund return is not one of these. We also reject the direct-demand hypothesis, using foreign fund 
flows and returns. We left with the conclusion that investor supply and demand we identify on a small group of funds is a instrument for market-level shifts in supply and demand for different types of assets on a daily basis. This may be due to the existence of behavioral factors per se such as market sentiment, or alternatively, flows and returns may both be correlated to an unidentified additional factor in the economy. 


\section{References}

Alpert M. and Raiffa H, 1992, " A progress report on training of probability assessors", in Judgement Under Uncertainty: Heuristics and Biases, Cambridge University Press.

Barber B. and T. Odean, 1999, "Boys will be boys: gender, overconfidence and common stock investment", W.P. University of California at Davis

Barberis N. A. Shleifer and R.Visny, 1998, " A model of Investor Sentiment," Working Paper, Havard Economics Department, 1998.

Beneish M.D. and R. Whaley, 1996, "An Anatomy of the 'S\&P Game': The Effects of Changing the Rules", Journal of Finance December, 1909-1930.

Brennan M.J. and H.H. Cao, 1997, " International portfolio investment flows", Journal of Finance 52, 1851-1880.

Brown, Stephen J., 1989, "The Number of Factors in Security Returns," Journal of Finance, 44(5), 1247-1262.

Campbell J., Grossman S. and J. Wang., 1992 "Trading volume and serial correlations in stock returns", NBER Working Paper \#4193

Chan L. and J. Lakonishok, 1995, "The Behavior of Stock Prices Around Institutional Trades", Journal of Finance, 1147-74.

Chan L. and J. Lakonishok, 1993, "Institutional Trades and Intraday Stock Price Behavior", Journal 
of Financial Economics, 33(2), 173-99.

Chan L., Jegadeesh N. and J. Lakonishok, 1996, "Momentum strategies", Journal of Finance, 51(5), 1681-1711.

Conner G. and R. Korajczyk, 1988, "Risk and Return in Equilibrium APT: Application of a New Test Methodology," Journal of Financial Economics, 21(2) pp. 255-290.

Conrad J. and G. Kaul, 1998, "An anatomy of trading strategies", The Review of Financial Studies, 11(3), 489-519.

Daniel K. D., Hirshleifer and A. Subrahmanyam, 1998, "A theory of Over-confidence, selfAttribution and Security Market Over and Under reactions," working paper, UCLA.

De Bondt W. F. M. and R. Thaler, 1985, "Does the Stock Market Overreact"" Journal of Finance, Vol. 40, No. 3, 793-805.

De-Long J. B., A. Shleifer, L. H. Summers and R. J. Waldmann, 1990, "Positive Feedback Investment Strategies and Destabilizing Rational Speculation", Journal of Finance, 45(2), 379-395.

Dhillon U.S. and H. Johnson, 1991, "Changes in the Standard and Poor"s 500 List", Journal of Business, 64(1), 75-85.

Edwards W., 1968, "Conservatism in human information processing", in Formal representation of human judgement, John Wiley and Sons, New York, pp, 17-52.

Fama E. and J. D. MacBeth, 1974, "Long-Term Growth in a Short-Term Market," Journal of 
Finance, Vol. 29, No. 3.., pp. 857-885.

Ferson W. and V. A. Warther, 1995, "Evaluating Fund Performance in a DynamicMarket", Financial Analysts Journal.

Froot K..A., O"Connell, P.G.J. and M. Seasholes M, (1998), "The portfolio flows of international investors, I", NBER Working Paper, \# 6687.

Garry M. and W. Goetzmann, 1986, "Does de-listing from the S\&P500 affect stock price?", Financial Analysts Journal, 42(2) 64-69.

Gompers P. and A. Metric, 1998, "How re Large Institutions Different From Other Investors" Why do These Differences Matter?" NBER Working Paper.

Goetzmann W. and M. Massa (1999) "Index fund investors", NBER Working Paper 7033.

Goetzmann, W., Z. Ivković, and K. G. Rouwenhorst, 1999, "Day Trading International Mutual Funds:

Evidence and Policy Solutions," Yale International Center for Finance Working Paper.

Grinblatt M., Titman, S. and R. Wermers, 1995, " Momentum Investment Strategies, Portfolio Performance, and Herding: A Study of Mutual Fund Behavior", American-Economic-Review; 85(5), 1088-1105.

Grinblatt M. and M. Keloharju, 1999, " Distance bias, language bias and investors sophistication: results from Finland", Mimeo UCLA 
Grinblatt M. and M. Keloharju, 1999, "What makes investors trade?", Mimeo UCLA

Grinblatt M. and M. Keloharju, 1998, " The investment behavior and performances of various investor-types: A study of Finland's unique data set" , Journal of Financial Economics, forthcoming

Harris L. and Gurel, 1986, "Price and Volume Effects Associated with Changes in the Standard and Poors 500 List -- New Evidence for the Existence of Price Pressures" Journal of Finance 41: (4) 815-829.

Hirshleifer D., A. Subrahmanyam and S. Titman, 1994, "Security Analysis and Trading Patterns when Some Investors Receive Information Before Others," Journal of Finance, Vol. 49, No. 5. (Dec), pp. 1665-1698.

Holthausen R.W., Leftwich R.W. and Mayers D., 1990, "Large Block Transactions, the Speed of Response, and Temprary and Permanent Stock Price Effects", Journal of Financial Economics, 26(1), 71-95.

Hong H. and J. Stein, 1999, "A Unified Theory of Underreaction, Momentum Trading and Overreaction in Asset Markets," Forthcoming, Journal of Finance.

Jeegadesh N. and S. Titman, 1993, "Returns to buying winners and losers, implications for stock market efficiency", Journal of Finance, 48, 65-92

Jeegadesh N. and S. Titman, 1995, "Overreaction, delayed reaction and contrarian profits", The Review of Financial Studies, 8(4), 973-993.

Kahnemann D. and A. Tversky, 1979, " Prospect theory: an analysis of decision under risk", 
Econometrica, 47, 263-291.

Lakonishok J. and A. Shleifer, 1992, "The Impact of Institutional Trading on Stock Prices", Journal of Financial Economics, 32(1), 23-43.

Lakonishok J., 1991, "Window Dressing by Pension Fund Managers", American Economic Review, 81(2), 227-31.

Lakonishok J., A. Shleifer and R. W. Vishny, 1991, "Do Institutional Investors Destabilize Stock Prices" Evidence on Herding and Feedback Trading" , NBER Working Paper: 3846.

Lee, Charles M. C., Andrei Shleifer, Richard H. Thaler, 1991, "Investor Sentiment and the Closed-End Fund Puzzle," Journal of Finance, Vol. 46, No. 1. (March), pp. 75-109.

Lehmann B. N. and D. Modest, 1988, "The Empirical Foundation of the Arbitrage Pricing Theory," Journal of Financial Economics, 21(2) pp. 213-254.

Lewellen W.G., Lease R.C. and G.C. Schlarbaum, 1979, "Investment performance and investor behavior", Journal of Financial and Quantitative Analysis", 14(1), 29-57.

Levy R. L., 1967, "Relative Strength as a Criterion for Investment Selection," Journal of Finance, Vol. 22, No. 4. (Dec.), pp. 595-610.

Lo A.W. and A.C. MacKinlay, 1990, "When are Contrarian Profits Due to Stock Market Overreaction"" Review of Financial Studies, Vol. 3, No. 2. , pp. 175-205.

Lynch A. W. and R.R, Mendenhall, 1997, "New evidence on stock price effects associated with 
changes in the S\&P500 index", Journal of Business 70: (3) 351-383.

Miller M. H., Muthuswamy J, and R.E. Whaley, 1994, "Mean reversion of Standard and Poor"s 500 Index Basis Changes: Arbitrage Induced or Statistical Illusion?" , Journal of Finance 49: (2) 479513.

Mikkelson W. H. , M.M.Partch and K Shah, 1997, "Ownership and Operating Performance of the Companies that go Public", Journal of Financial Economics, 44(3), 281-307.

Odean T. ,1998 "Are Investors Reluctant to Realize Their Losses", Journal-of-Finance; 53(5), 17751798.

Orosel G., 1998, "Participation costs, Trend-Chasing, and Volatiilty of Stock Prices," The Review of Financial Studies 11(3), p. 521-558.

Roll R. and S. A. Ross, 1980, "An Empirical Investigation of the Arbitrage Pricing Theory," Journal of Finance, Vol. 35, No. 5., pp. 1073-1103.

Rosenberg B., K. Reid and R. Lanstein, 1984, "Persuasive Evidence of Market Inefficiency," Jounral of Portfolio Management, 11(3) 9-17.

Ross, Stephen A., 1976, "The Arbitrage Theory of Capital Asset Pricing," Journal of Economic Theory, 3 (December), 346-362.

Ross, Stephen A., 1978, "Mutual Fund Separation in Finance Theory -- The Separating Distributions," Journal of Economic Theory, 17, 254-256. 
Shiller R, (1998) "Comment on Vincent Warther, "Has the Rise of Mutual Funds Increased Market Instability" Brooking-Wharton Papers

Shleifer A., July 1986, Do Demand Curves for Stocks Slope Down", Journal of Finance, 41(3), 579-590.

Sias R.W. and Starks, L.T. (1996) "Return Autocorrelation and Institutional Investors", Journal of Financial Economics, 46, 103-31.

Sirri E. R. and Tufano P. (1993), "Buying and selling mutual funds: flows, performance, fees and service", Working Paper, Harvard Business School.

Stulz R. M., 1997, "Do foreign investors destabilize stock markets? The Korean experience in 1997", Mimeo, Charles A. Dice Center for Research in Financial Economics.

Stulz R. M., 1999, "International portfolio flows and security markets", Mimeo, The Ohio State University.

Whaley R. E. and D. Messod, 1996, "An Anatomy of the "S\&P Game": The Effects of Changing the Rules", Journal of Finance; 51(5), 1909-30.

Warther V. A., 1995, "Aggregate Mutual Fund Flows and Security returns", Journal of Financial Economics, 39, 209-235.

Whaley R. E. and Messod, 1996, D. "An Anatomy of the "S\&P Game": The Effects of Changing the Rules", Journal of Finance; 51(5), 1909-30. 
Whaley R., M.H. Miller and J. Muthuswamy 1994, "Mean Reversion of S\&P500 Index Basis Changes: Arbitrage-Induced or Statistical Illusion"', Journal of Finance 49, 479-513.

Zheng L. 1997, "Stock Prices and Investment Cash Flows," Yale School of Management Working Paper, 1997.

Zheng L., 1998, "Who Moves the Market," Working Paper, University of Michigan Business School.

Zheng L. 1999, "Stock Market Volatility and Investment," Essay in Ph.D. Thesis, Yale School of Management. 
Table 1: Fund Objectives and Classifications

The table cross-tabulates the objectives of the funds in the TrimTabs sample with eight asset classes used in the analysis. "NA" indicates not classified, "C" is for a cash fund,"FB" indicates Foriegn bonds", "FEQ" indicates non-U.S. equity funds, "M" indicates precious metal funds, "MU" indicates municipal bond funds,"USEQ" indicates U.S. equity funds, "USB" indicates U.S. bond funds, "S" indicates U.S. sector funds, excluding precious metals.

\begin{tabular}{|c|c|c|c|c|c|c|c|c|c|}
\hline & NA & $\mathrm{C}$ & FB & FEQ & $\mathrm{M}$ & $\mathrm{Mu}$ & $\mathrm{S}$ & USB & USEQ \\
\hline Convertibles & 0 & 0 & 0 & 0 & 0 & 0 & 0 & 7 & 0 \\
\hline Diversified Emerging Mkts & 0 & 0 & 0 & 11 & 0 & 0 & 0 & 0 & 0 \\
\hline Diversified Pacific/Asia Stock & 0 & 0 & 0 & 4 & 0 & 0 & 0 & 0 & 0 \\
\hline Domestic Hybrid & 52 & 0 & 0 & 0 & 0 & 0 & 0 & 0 & 0 \\
\hline Emerg Mkts Bond & 0 & 0 & 3 & 0 & 0 & 0 & 0 & 0 & 0 \\
\hline Europe Stock & 0 & 0 & 0 & 4 & 0 & 0 & 0 & 0 & 0 \\
\hline Foreign Stock & 0 & 0 & 0 & 48 & 0 & 0 & 0 & 0 & 0 \\
\hline High Yield Bond & 0 & 0 & 0 & 0 & 0 & 0 & 0 & 41 & 0 \\
\hline Intermediate Government & 0 & 0 & 0 & 0 & 0 & 0 & 0 & 35 & 0 \\
\hline Intermediate-term Bond & 0 & 0 & 0 & 0 & 0 & 0 & 0 & 30 & 0 \\
\hline International Bond & 0 & 0 & 24 & 0 & 0 & 0 & 0 & 0 & 0 \\
\hline International Hybrid & 8 & 0 & 0 & 0 & 0 & 0 & 0 & 0 & 0 \\
\hline Japan Stock & 0 & 0 & 0 & 2 & 0 & 0 & 0 & 0 & 0 \\
\hline Large Blend & 0 & 0 & 0 & 0 & 0 & 0 & 0 & 0 & 88 \\
\hline Large Growth & 0 & 0 & 0 & 0 & 0 & 0 & 0 & 0 & 68 \\
\hline Large Value & 0 & 0 & 0 & 0 & 0 & 0 & 0 & 0 & 82 \\
\hline Latin America Stock & 0 & 0 & 0 & 5 & 0 & 0 & 0 & 0 & 0 \\
\hline Long Government & 0 & 0 & 0 & 0 & 0 & 0 & 0 & 1 & 0 \\
\hline Long-term Bond & 0 & 0 & 0 & 0 & 0 & 0 & 0 & 6 & 0 \\
\hline Mid-Cap Blend & 0 & 0 & 0 & 0 & 0 & 0 & 0 & 0 & 24 \\
\hline Mid-Cap Growth & 0 & 0 & 0 & 0 & 0 & 0 & 0 & 0 & 46 \\
\hline Mid-Cap Value & 0 & 0 & 0 & 0 & 0 & 0 & 0 & 0 & 19 \\
\hline Multisector Bond & 0 & 0 & 0 & 0 & 0 & 0 & 0 & 18 & 0 \\
\hline Muni CA Interm & 0 & 0 & 0 & 0 & 0 & 1 & 0 & 0 & 0 \\
\hline Muni CA Long & 0 & 0 & 0 & 0 & 0 & 17 & 0 & 0 & 0 \\
\hline Muni NY Interm & 0 & 0 & 0 & 0 & 0 & 2 & 0 & 0 & 0 \\
\hline Muni NY Long & 0 & 0 & 0 & 0 & 0 & 10 & 0 & 0 & 0 \\
\hline Muni National Interm & 0 & 0 & 0 & 0 & 0 & 16 & 0 & 0 & 0 \\
\hline Muni National Long & 0 & 0 & 0 & 0 & 0 & 43 & 0 & 0 & 0 \\
\hline Muni Short & 0 & 0 & 0 & 0 & 0 & 4 & 0 & 0 & 0 \\
\hline Muni Single state Interm & 0 & 0 & 0 & 0 & 0 & 3 & 0 & 0 & 0 \\
\hline Muni Single state Long & 0 & 0 & 0 & 0 & 0 & 28 & 0 & 0 & 0 \\
\hline Pacific/Asia ex-Japan Stock & 0 & 0 & 0 & 11 & 0 & 0 & 0 & 0 & 0 \\
\hline Short Government & 0 & 17 & 0 & 0 & 0 & 0 & 0 & 0 & 0 \\
\hline Short-term Bond & 0 & 12 & 0 & 0 & 0 & 0 & 0 & 0 & 0 \\
\hline Small Blend & 0 & 0 & 0 & 0 & 0 & 0 & 0 & 0 & 12 \\
\hline Small Growth & 0 & 0 & 0 & 0 & 0 & 0 & 0 & 0 & 32 \\
\hline Small Value & 0 & 0 & 0 & 0 & 0 & 0 & 0 & 0 & 20 \\
\hline Specialty-Communication & 0 & 0 & 0 & 0 & 0 & 0 & 5 & 0 & 0 \\
\hline Specialty-Financial & 0 & 0 & 0 & 0 & 0 & 0 & 5 & 0 & 0 \\
\hline Specialty-Health & 0 & 0 & 0 & 0 & 0 & 0 & 4 & 0 & 0 \\
\hline Specialty-Natural Res & 0 & 0 & 0 & 0 & 0 & 0 & 2 & 0 & 0 \\
\hline Specialty-Precious Metals & 0 & 0 & 0 & 0 & 8 & 0 & 0 & 0 & 0 \\
\hline Specialty-Real Estate & 0 & 0 & 0 & 0 & 0 & 0 & 6 & 0 & 0 \\
\hline Specialty-Technology & 0 & 0 & 0 & 0 & 0 & 0 & 6 & 0 & 0 \\
\hline Specialty-Unaligned & 0 & 0 & 0 & 0 & 0 & 0 & 2 & 0 & 0 \\
\hline Specialty-Utilities & 0 & 0 & 0 & 0 & 0 & 0 & 13 & 0 & 0 \\
\hline Ultrashort Bond & 0 & 3 & 0 & 0 & 0 & 0 & 0 & 0 & 0 \\
\hline World Stock & 34 & 0 & 0 & 0 & 0 & 0 & 0 & 0 & 0 \\
\hline
\end{tabular}


Table 2: Correlations Across Flows and Returns for Major Asset Classes

The top two panels of the table reports the correlations by category for net cash flows into fund categories. "Net Cash Flows" are calculated by summing the net flows into all funds in the category each day. "Equal-Weighted Average Percentage Flow" for each asset class is calculated by equally weighting the percentage daily change in fund value due to net purchase or sale of fund shares. "Equal-Weighted Fund Returns" is calculated as the equal-weighted average of fund returns within the asset class.

Net Dollar Flows

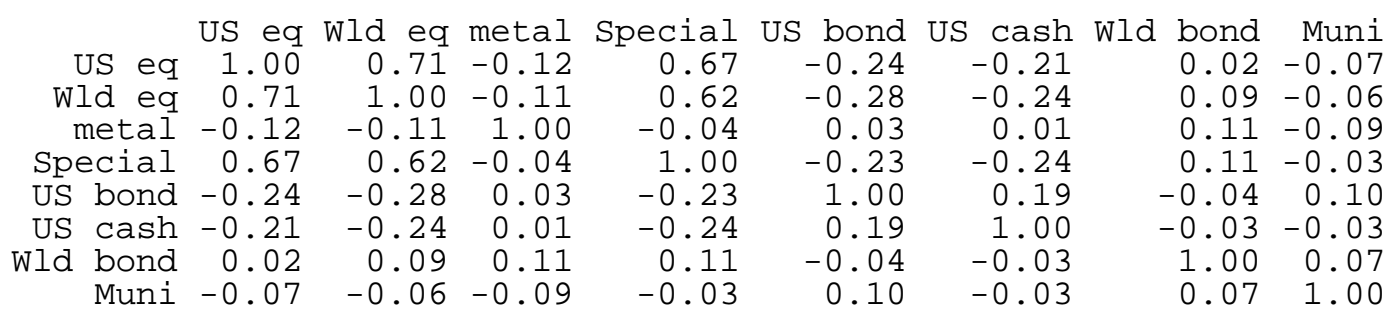

Equal-Weighted Average Percentage Flow

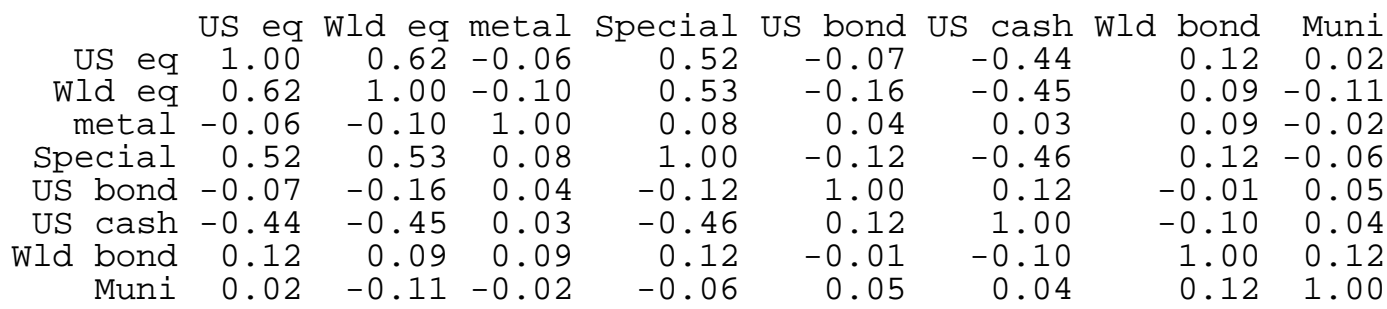

Equal-Weighted Fund Returns

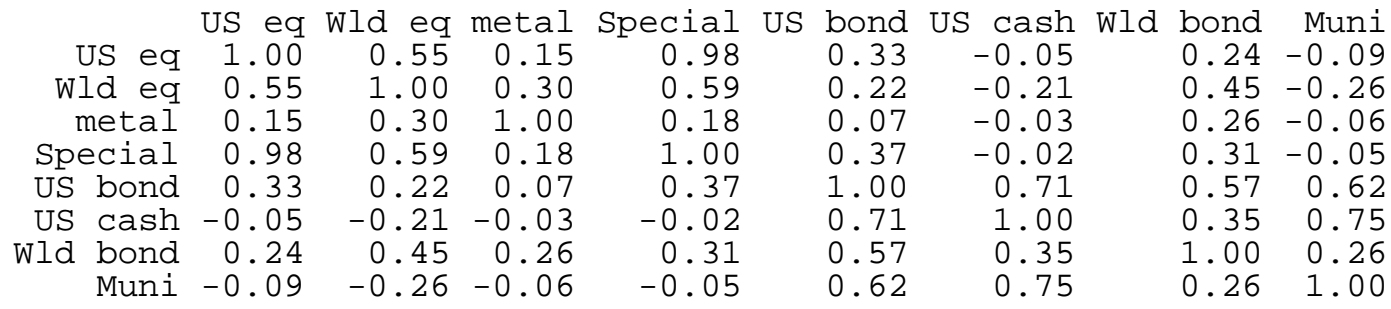

Cross-Correlations: Net Dollar Flows to Equal-Weighted Fund Returns (Flows in rows, returns in columns)

\begin{tabular}{|c|c|c|c|c|c|c|c|c|}
\hline & US eq & Wld & metal & ecial & US bond & cash & ld bond & lou \\
\hline US eq & 0.19 & 0.05 & -0.03 & 0.09 & -0.05 & -0.06 & -0.04 & -0.0 \\
\hline wld eq & 0.36 & 0.29 & 0.03 & 0.23 & -0.08 & -0.08 & -0.05 & -0.1 \\
\hline metal & 0.05 & -0.01 & 0.30 & 0.04 & 0.07 & -0.02 & -0.03 & 0 \\
\hline Special & 0.20 & 0.04 & -0.01 & 0.07 & -0.06 & -0.06 & -0.05 & -0 \\
\hline US bond & 0.14 & 06 & -0.08 & 12 & 0.07 & -0.04 & 0.07 & -0 \\
\hline US cash & -0 . & -0 & -0 & 0.06 & 00 & 01 & 0.07 & \\
\hline Wld bond & 0. & 0 & -0 & .12 & 0.00 & -0 & -0.06 & \\
\hline Muni & 0 . & & -0 & 0.09 & 0.07 & & 0.06 & \\
\hline
\end{tabular}


Table 3: Principal Component Loadings By Objective

Weights for the first four principal components constructed from capital weighted flows of the fund objective classifications. "NA" indicates that we were unable to identify the fund objective by cross-indexing with the Morningstar database. All other categories are self-explanatory.

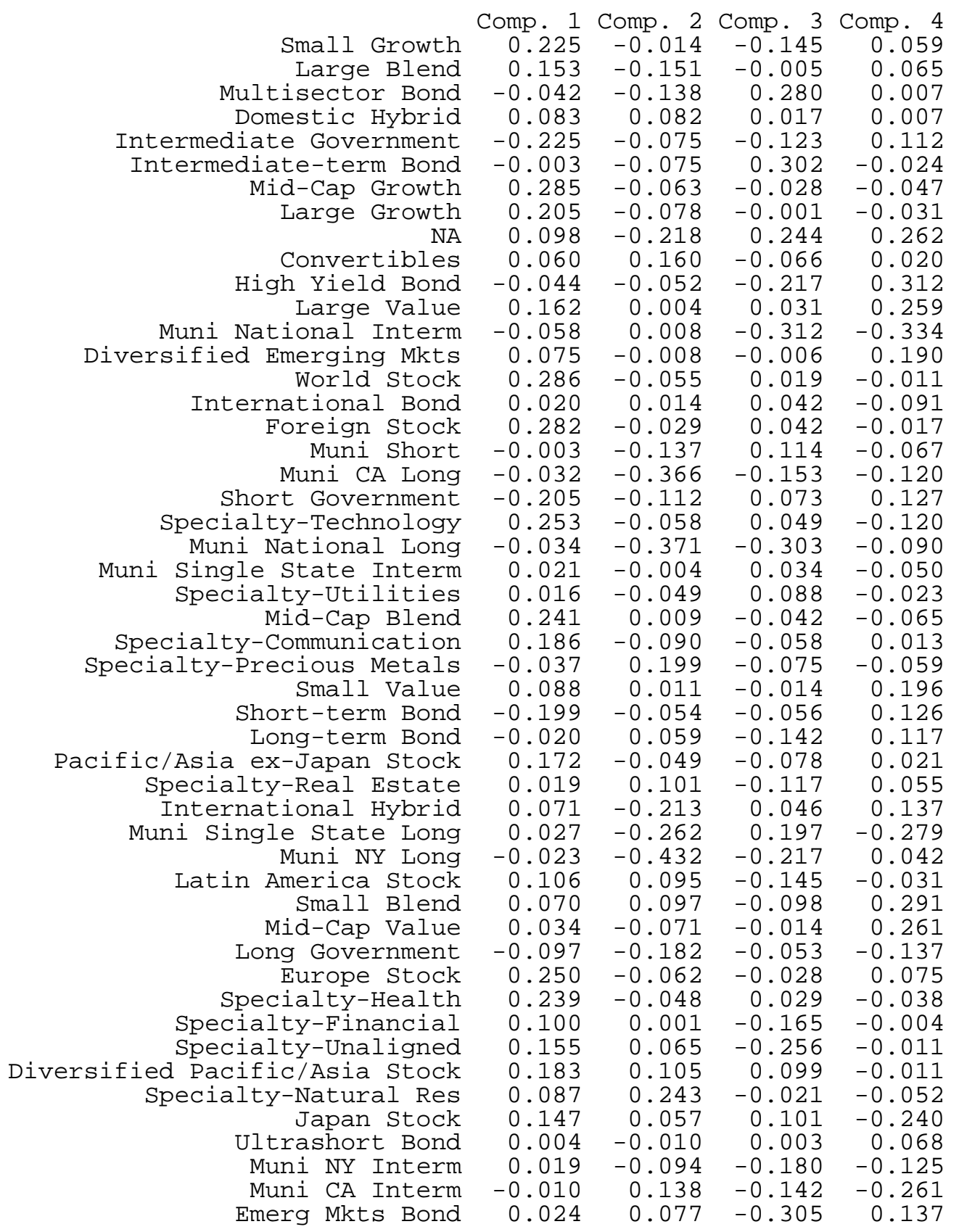


Table 4: Principal Component Loadings by Asset Class

Weights for all eight principal components constructed from capital weighted flows of the major asset classes, and from equal-weighted returns from the major asset classes The percentage of variation explained by each component is below.

Flow Factors

\begin{tabular}{|c|c|c|c|c|c|c|c|c|}
\hline $\begin{array}{r}\text { US eq } \\
\text { Wld eq } \\
\text { metal } \\
\text { Special } \\
\text { US bond } \\
\text { US cash } \\
\text { Wld bond } \\
\text { Muni }\end{array}$ & $\begin{array}{r}\text { Comp. } 1 \\
-0.5035 \\
-0.5149 \\
0.0285 \\
-0.4880 \\
0.1504 \\
0.4474 \\
-0.1278 \\
0.0565\end{array}$ & $\begin{array}{r}\text { Comp. } 2 \\
0.0604 \\
-0.1132 \\
0.4241 \\
0.0759 \\
0.2937 \\
0.0052 \\
0.6332 \\
0.5574\end{array}$ & $\begin{array}{r}\text { Comp. } 3 \\
0.1153 \\
0.0518 \\
-0.7874 \\
-0.1691 \\
-0.0033 \\
-0.0057 \\
0.0388 \\
0.5778\end{array}$ & $\begin{array}{r}\text { Comp. } 4 \\
0.1752 \\
0.0731 \\
-0.0760 \\
0.0572 \\
0.9246 \\
-0.0340 \\
-0.2971 \\
-0.1034\end{array}$ & $\begin{array}{r}\text { Comp. } 5 \\
0.0674 \\
-0.0479 \\
0.3625 \\
0.1287 \\
-0.1522 \\
-0.0830 \\
-0.7018 \\
0.5679\end{array}$ & $\begin{array}{r}\text { Comp. } 6 \\
0.3591 \\
0.3282 \\
0.0644 \\
0.0674 \\
-0.0649 \\
0.8660 \\
-0.0178 \\
0.0159\end{array}$ & $\begin{array}{r}\text { Comp. } 7 \\
0.3466 \\
0.2815 \\
0.2347 \\
-0.8381 \\
-0.0285 \\
-0.2045 \\
-0.0055 \\
-0.0217\end{array}$ & $\begin{array}{r}\text { Comp. } 8 \\
-0.6672 \\
0.7245 \\
0.0541 \\
-0.0251 \\
0.0901 \\
0.0044 \\
-0.0009 \\
0.1352\end{array}$ \\
\hline Exp Var. & 0.323 & 0.1463 & 0.1301 & 0.1193 & 0.1022 & 0.0761 & 0.0584 & 0.0447 \\
\hline $\begin{array}{r}\text { US eq } \\
\text { Wld eq } \\
\text { metal } \\
\text { Special } \\
\text { US bond } \\
\text { US cash } \\
\text { Wld bond } \\
\text { Muni }\end{array}$ & $\begin{array}{r}\text { Comp. } 1 \\
0.4264 \\
0.3540 \\
0.1767 \\
0.4531 \\
0.4454 \\
0.2397 \\
0.4048 \\
0.1915\end{array}$ & $\begin{array}{r}\text { Comp. } 2 \\
-0.3075 \\
-0.3564 \\
-0.1399 \\
-0.2897 \\
0.3240 \\
0.5275 \\
0.1013 \\
0.5305\end{array}$ & $\begin{array}{r}\text { Comp. } 3 \\
0.3725 \\
-0.1868 \\
-0.7516 \\
0.3242 \\
0.0584 \\
0.0309 \\
-0.3823 \\
0.0757\end{array}$ & $\begin{array}{r}\text { Comp. } 4 \\
0.2579 \\
-0.3908 \\
0.6171 \\
0.2213 \\
-0.0574 \\
0.1089 \\
-0.5435 \\
0.2011\end{array}$ & $\begin{array}{r}\text { Comp. } 5 \\
-0.1783 \\
0.6996 \\
0.0020 \\
-0.1732 \\
0.2106 \\
0.0046 \\
-0.5842 \\
0.2511\end{array}$ & $\begin{array}{r}\text { Comp. } 6 \\
0.0175 \\
0.0164 \\
-0.0307 \\
0.0821 \\
-0.3093 \\
-0.5436 \\
0.1963 \\
0.7497\end{array}$ & $\begin{array}{r}\text { Comp. } 7 \\
-0.0766 \\
-0.2643 \\
0.0486 \\
-0.0671 \\
0.7416 \\
-0.5963 \\
-0.0517 \\
-0.0959\end{array}$ & $\begin{array}{r}\text { Comp. } 8 \\
-0.6931 \\
-0.0202 \\
-0.0102 \\
0.7179 \\
-0.0036 \\
0.0216 \\
-0.0426 \\
-0.0370\end{array}$ \\
\hline Exp.Var. & 0.383 & 0.36 & 0.13 & & 0.0390 & 0.0323 & 0.0 & 0.0022 \\
\hline
\end{tabular}


Table 5: Correlations of Orthogonalized Flows

Correlation matrix of equal-weighted relative percentage fund flows orthogonalized with respect to the returns for each asset class.

\begin{tabular}{|c|c|c|c|c|c|c|c|c|c|}
\hline & US eq & Ild & metal & Special & & & Wld & & \\
\hline US eq & $00^{+}$ & 0.59 & -0.0 & & & -0.40 & & & 0.04 \\
\hline Wld eq & 0.59 & 1.00 & -0.09 & 0.53 & -0.30 & -0.42 & & & \\
\hline Metal & -0.09 & -0.09 & 1.00 & 0.07 & 0.03 & 0.03 & & 0.05 & -0.04 \\
\hline pecial & & 0.53 & 0.07 & 1.00 & -0.24 & -0.42 & & 0.17 & .04 \\
\hline US bond & -0 & -0 & 0.03 & & 1.00 & 0.17 & & -0.05 & 0.03 \\
\hline US cash & -0.40 & -0.42 & 0.0 & & 0 . & 1. & & -0 & 0.0 \\
\hline Wld bond & 0.1 & 0 & 0.0 & 0 . & -0.05 & -0.11 & & 1.00 & 0.11 \\
\hline Mun & 0 & -0 . & -0 . & -0 . & & 0.02 & & 0.11 & \\
\hline
\end{tabular}


Table 6: Controlling for Non-Trading

Mean and median t-statistics and $R^{2}$ from second-stage RR regressions. Return factors are the daily time series of returns to the eight major asset classes. Orthogonalized factors are the flows of the eight major asset classes orthogonalized with respect to the asset class returns by using the residuals from the time-series regressions of the flow factors on the set of eight asset class return portfolios. "twice-orthogonalized factors," are the residuals obtained by regressing asset class flows on contemporaneous and previous-day returns to eight asset class return portfolios.

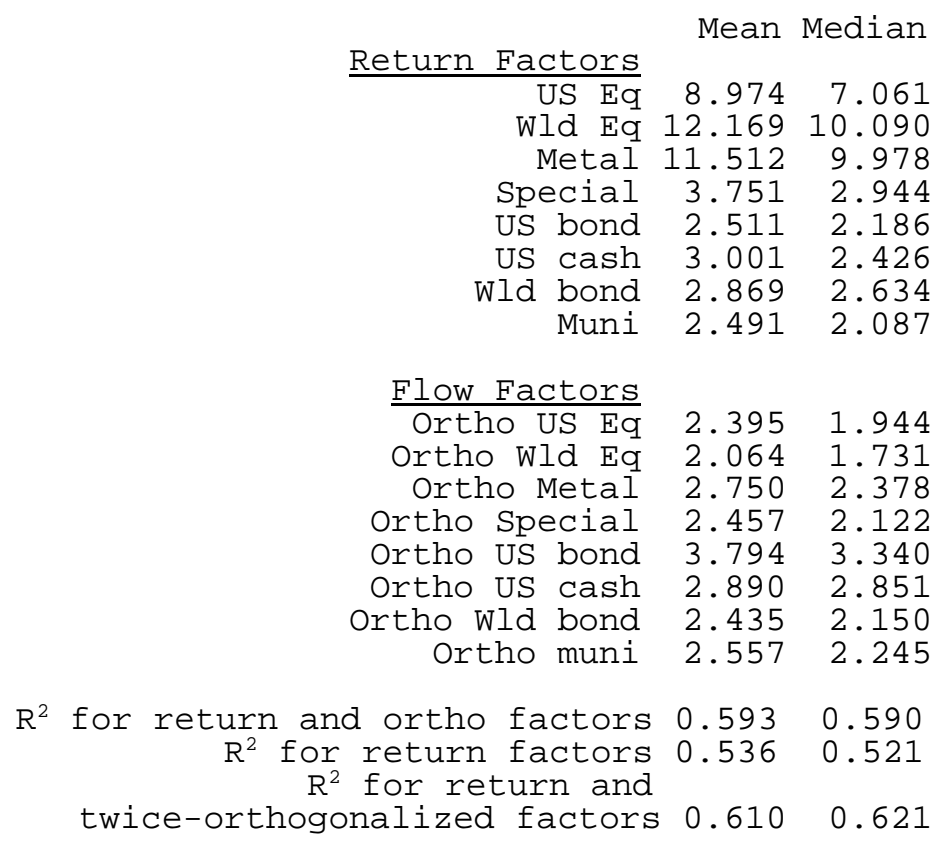


Table 7: Controlling for Fund Objectives and Non-Trading

Mean and median t-statistics and $\mathrm{R}^{2}$ from second-stage $\mathrm{R}$ regressions, using dummies for all objectives (other than U.S. Equity). Return factors are the daily time series of returns to the eight major asset classes. Orthogonalized factors are the flows of the eight major asset classes orthogonalized with respect to the asset class returns and their lagged values by using the residuals from the time-series regressions of the flow factors on the set of eight asset class contemporaneous and previous day return portfolios.

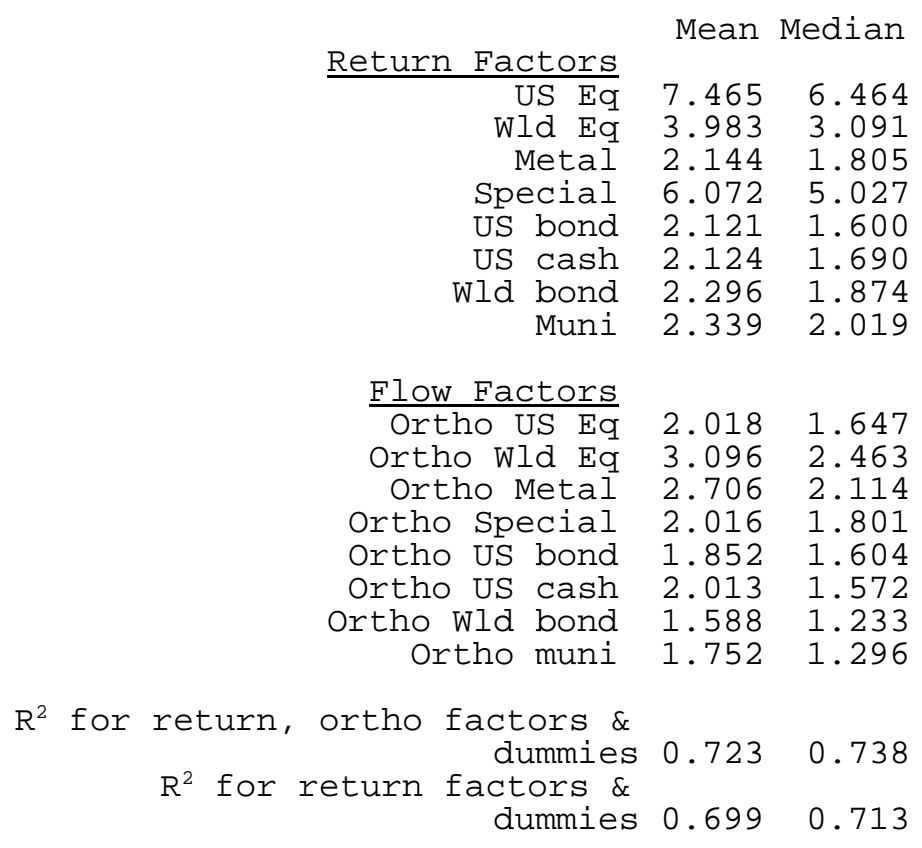


Notes:

${ }^{1}$ In particular, Kahneman and Tversky (1974) identify the heuristics called "representativeness," or the tendency to view events as typical or representative of some specific class without paying attention to the laws of probability that generate them. Edwards (1968) focusses on "conservatism", that is the tendency of individuals to slowly update their mental models as new evidence comes by. Barberis, Shleifer and Vishny (1998) use these findings to describe investor behavior. Alpert and Raiffa (1982) identify the "overstimation bias" -- people tend to overestimate the precision of their knowledge. Daniel, Hirshleifer and Subrahmanyam (1998) and Odean (1998) show how overconfidence plays a role in financial markets, by increasing trading volume and affecting asset prices. More recently Hong and Stein (1999) explain investor behavior on the basis of common psychological heuristics, while Odean (1998) and Grinblatt and Kellaharin (1999), show evidence that investors tend to display "loss aversion."

${ }^{2}$ For example, Holthausen, Leftwich and Mayers (1984) find evidence of temporary price pressure on individual securities in cases of unusual demand or supply.

${ }^{3}$ The role played by big financial investors has been analyzed by Lakonishok, Shleifer and Vishny (1991) and Chan and Lakonishok (1993, 1995). The former find the purchase of stocks by institutions drives prices up, while the latter directly identify the price reactions to institutional trades. In the international finance literature Froot, O'Connell and Seascholes (1998) and Stulz $(1998,1999)$ show the role played by the class of the international investors. International inflows, even the transitory ones, are shown to have a positive future impact on returns. Grinblatt and Kelloharin (1999) report that foreign investors alone significantly correlates to price changes in the most active stocks in Finland.

${ }^{4}$ Warther (1995) and Zheng (1997), using quarterly and monthly data data, find evidence of impact of some aggregated flows on to the level of the stock market. Zheng (1998) looks at the investment sector flows and finds that quarterly institutional demand shocks are contemporaneously correlated to stock market returns. Goetzmann and Massa (1998) and Edelen and Warner (1999) find that short-term fluctuations in aggregate investor demand for stocks is correlated to contemporaneous price changes and thus may move security prices. Using daily index fund flows, Goetzmann and Massa also show a strong contemporaneous correlation between fund inflows and S\&P market returns and no evidence for positive feedback trading. Supporting the hypothesis of causality from flows to returns.

${ }^{5}$ One potential concern about the calculation of flow is whether customer orders earlier in the day might induce a correlation between flow and return. For example, suppose a billion dollar index fund, with a share price of $\$ 1$ received a purchase order at 9:00 AM for 100 million shares. Knowing that asset will grown by roughly $\$ 100$ million, the manager might purchase securities on credit in the morning -- effectively increasing the NAVPS in the morning by $10 \%$ through leverage. Since transactions are settled at the close of the day prices this amounts to a day's use of the money. Now suppose the market return on the day was $10 \%$. The existing shareholders in the fund effectively made $11 \%$ on their money on that day because of the leverage. Note that even in this extreme case in which the flow represented a significant percentage of fund assets 
and the daily return was quite large, the primary factor affecting the magnitude of the correlation between the inflow and the return is the sign of the return. The leverage effect simply scales the return on the day, rather than affecting it positively. Had the market dropped by $10 \%$, the correlation between flow and return would have been negative for the day. If net cash flows into funds actually affected security prices, the daily flows themselves may be useful timing information to fund managers for purposes of market timing. This activity would induce a larger positive relationship between flows and daily returns, however it is conditional upon the effect. The above example presumes the manager is aware of the intra-day demand. While this may be true for some types of funds (like index funds) it may not be generally the case, thus, even the extreme case is hypothetical.

${ }^{6}$ We thank John Ameriks of TIAA-CREF for this observation. For detailed discussion on adjustment methods, see Greene and Hodges (2000) and Goetzmann, Ivković and Rouwenhorst (1999).

7 At the time of writing, we are currently identifying the funds in the sample of 999 which report late using the methods in Goetzmann, Ivković and Rouwenhorst (1999)

${ }^{8}$ With two exceptions. We removed funds that are hybrid stock-bond funds and also funds that held both U.S. and foreign equities. The logic of this is that we wanted to calculation correlation and factors as much as possible in terms of "pure plays."

${ }^{9}$ To check for seasonality, we ran a regression of net flows into U.S. stock funds on a dummy matrix indicating the day of the week. We found no evidence of weekday differences in flows . ${ }^{10}$ The regressions used to create the orthogonalized flows for each of the eight asset class flow series? typically show significant explanatory power on one or more variables with $10 \%$ to $20 \%$ variation explained. Thus, as might be expected from the cross-correlations, the flows are not orthogonal to returns.

11 The need for twice-orthogonalization is due to a simple non-synchronous trading story. For example, suppose that investors chased asset classes that did well the previous day. Flows would then be instruments for yesterday's asset class returns. Many of the funds may hold securities that trade infrequently, which would induce an autocorrelation in returns. In fact, we test for daily autocorrelation in fund returns and we find we can reject the null, on average, for the sample. In this circumstance, we would expect that loadings on the previous-day's asset class return should spread today' s fund performance. Further, we should expect that the loadings on contemporaneous return factor realizations should have a relatively low explanatory power. By orthogonalizing flows with respect to previous-day returns, we remove this as a potential explanation for the effect.

${ }^{12}$ Brown and Goetzmann (1997) find that reported objectives do not perform as well as endogenously determined styles in a Fama-MacBeth framework, however these tests were based upon equity funds and a limited number of objectives. We use all fifty objectives in this test. While endogenously determined styles might improve the result, they would also likely capture behavioral factor effects to the extent they are common across funds. 
